\title{
Effects Of Estuarine Acidification On An Oyster-Associated Community In New South Wales, Australia
}

Cassandra N. Glaspie

Virginia Institute of Marine Science

SR Jenkinson

RD Seitz

Virginia Institute of Marine Science

Follow this and additional works at: https://scholarworks.wm.edu/vimsarticles

Part of the Marine Biology Commons

\section{Recommended Citation}

Glaspie, Cassandra N.; Jenkinson, SR; and Seitz, RD, "Effects Of Estuarine Acidification On An OysterAssociated Community In New South Wales, Australia" (2018). VIMS Articles. 298.

https://scholarworks.wm.edu/vimsarticles/298

This Article is brought to you for free and open access by the Virginia Institute of Marine Science at W\&M ScholarWorks. It has been accepted for inclusion in VIMS Articles by an authorized administrator of W\&M ScholarWorks. For more information, please contact scholarworks@wm.edu. 


\title{
EFFECTS OF ESTUARINE ACIDIFICATION ON AN OYSTER-ASSOCIATED COMMUNITY IN NEW SOUTH WALES, AUSTRALIA
}

\author{
CASSANDRA N. GLASPIE, ${ }^{1 * \dagger}$ SARAH R. JENKINSON ${ }^{2}$ AND ROCHELLE D. SEITZ ${ }^{1}$ \\ ${ }^{1}$ Department of Biological Sciences, Virginia Institute of Marine Science, College of William \& Mary, \\ Gloucester Point, Virginia 23062; ${ }^{2}$ Department of Biological Sciences, Macquarie University, North \\ Ryde, Sydney, New South Wales 2109, Australia
}

\begin{abstract}
Many of the features that make estuaries among the most productive natural systems on earth also make them prone to acidification. Understanding the effects of estuarine acidification on different components of an ecological community is an important step in identifying indicators of ecosystem degradation. This study examined the impact of estuarine acidification, as a result of acid sulfate soil runoff, on wild Sydney rock oysters Saccostrea glomerata and their associated epifaunal communities in estuaries experiencing acid sulfate soil runoff in New South Wales, Australia. The responses of oysters and their invertebrate epifaunal communities to chronic acidification (greater than $6 \mathrm{mo}$; represented by oyster source site conditions) were assessed by examining the differences in oyster communities associated with moderate acidification ( $3.5 \mathrm{~km}$ from the source of acidification) or low acidification ( $8.2 \mathrm{~km}$ from the source). Oysters from moderate- or low-acidification sites were transplanted to a site with high exposure to acidification (less than $3 \mathrm{~km}$ from the source) or back to their original source sites (control) to mimic episodic acidification ( 2 wk). Epifaunal mussels Xenostrobus securis and limpets Patelloida mimula showed a negative association with oyster mortality, suggesting that these communities are closely tied to oyster survival. Oyster-associated epifaunal communities exposed to both chronic and episodic acidification were significantly different from communities with low exposure. Epifaunal communities exposed to episodic acidification were significantly less diverse than the control. Spionid and syllid worms were significantly less abundant and the mussel $X$. securis was significantly more abundant on oysters with moderate exposure or chronic exposure to acidification, as compared with communities from areas with low exposure to acidification. The mussel $X$. securis and the snail Bembicium auratum were significantly less abundant in oyster communities that were exposed to episodic acidification, as compared with the control. In systems where community composition depends on a single habitat-forming species, maintaining resistance may rely on the ability of that species to persist in the face of environmental stress.
\end{abstract}

KEY WORDS: gastropod, bivalve, estuarine acidification, multiple stressors, diversity

\section{INTRODUCTION}

Coastal ecosystems such as estuaries are some of the most productive natural systems on earth (Duarte et al. 2008). Many of the features that make estuaries so productive, including riverine input, high nutrient load, long residence times, and proximity to humans (Nixon et al. 1986, Josefson \& Rasmussen 2000, Nixon \& Buckley 2002, Whitfield 2016), also make estuaries prone to acidification (Cook et al. 2000, Howland et al. 2000, Feely et al. 2010, Cai et al. 2017). In estuarine environments, $\mathrm{pH}$ can vary on decadal (Waldbusser et al. 2011), seasonal (Howland et al. 2000), intra-annual (Provoost et al. 2010), or diel (Ringwood \& Keppler 2002) scales. Estuaries have naturally low pH buffering capacity (Cai et al. 2017); thus, estuarine acidification can be extreme, with $\mathrm{pH}$ less than 4 (Tulau 1999).

Estuaries characterized by acid sulfate soil runoff experience extreme acidification on both chronic and episodic timescales (Wilson \& Hyne 1997, Tulau 1999). Acid sulfate soils are formed by marine sediments containing sulfate-reducing bacteria and iron pyrite, which form sulfuric acid when oxygenated (Wilson \& Hyne 1997, Cook et al. 2000). This is a natural process but is exacerbated by changes in land use, especially drainage of land for agriculture purposes (Dent \& Pons 1995). Acidic water collects in drainage ditches and is distributed to surrounding water bodies via outflow drains, thereby exposing

*Corresponding author. E-mail: cassandra.glaspie@gmail.com $\dagger$ Present address: Department of Fisheries and Wildlife, Oregon State University, 104 Nash Hall, Corvallis, OR 97731.

DOI: $10.2983 / 035.037 .0105$ aquatic organisms to acidified environments (Wilson \& Hyne 1997). During rain events, pulses of acidified water may impact sites several $\mathrm{km}$ downstream of the outflow drain (RuizHalpern et al. 2015). These acidification events are short lived, on the order of days (Macdonald et al. 2007), weeks (Wilson et al. 1999), or rarely, months (Sammut et al. 1995). The nature of this variability may be important because whereas chronic stressors may lead to biodiversity loss and a decrease in ecosystem functioning, episodic disturbances may instead lead to increased resistance or resilience in populations (Rapport \& Whitford 1999).

The Hastings Estuary in coastal New South Wales (NSW), Australia, contains regions with high exposure to acid sulfate soil because of drainage and development (Tulau 1999). This estuary supports the grey mangrove Avicennia marina as well as productive reefs composed of the Sydney rock oyster Saccostrea glomerata, which grows attached to mangrove roots. Juvenile $S$. glomerata do not exhibit increased rates of mortality in acidified portions of the estuary; however, in the Hastings and similar estuaries in coastal NSW, areas with high exposure to acid sulfate soil drainage generally have fewer, slower-growing oysters than low-exposure areas (Amaral et al. 2011, 2012a). Crustacean and gastropod assemblages in areas exposed to chronic acidification are similar to those exposed to episodic acidification, with the exception of the gastropod Bembicium auratum, which was at least twice as abundant in areas with low exposure to acidification than in areas with high exposure (Amaral et al. 2011).

Understanding the effects of a stressor on different components of a community is an important step to predicting changes 
in ecosystem structure and functioning (Bulling et al. 2010) and identifying early warning signals that indicate lost resistance and the potential for a catastrophic shift in an ecosystem (Scheffer et al. 2001). Previous work to this effect has focused mainly on Saccostrea glomerata because oysters are ecosystem engineers that provide a surface for attachment in otherwise soft-bottom systems, modulate environmental stressors, and protect organisms from predation (Gutiérrez et al. 2003); however, oysters and associated species may have different tolerances to stressors, resulting in changes in the community that are asynchronous with those of oysters (Gedan \& Bertness 2010). In addition, communities may respond to environmental changes by exhibiting compensatory dynamics that lead to ecosystem stability (Gonzalez \& Loreau 2009). Because the organisms in the Hastings Estuary have been exposed to acidification for several decades, this setting is ideal for an assessment of community structure response under in situ extreme estuarine acidification.

A natural gradient in $\mathrm{pH}$, alkalinity, and salinity produced in an acid sulfate acidified estuary in NSW, Australia (Amaral et al. 2012a, 2012b), was used to (1) examine changes in mortality rates of oysters and oyster community composition after episodic ( $2 \mathrm{wk}$ ) exposure to acidified conditions (a period of time corresponding to an acid sulfate soil runoff event due to heavy precipitation); (2) examine how chronic exposure (greater than 6 mo, represented by oyster source site conditions) modify oyster and oyster community response to an episodic stressor; and (3) determine if oyster mortality data are correlated with patterns in abundance of associated epifaunal species.

\section{MATERIALS AND METHODS}

\section{Experimental Design}

To test for effects of acidification on oyster-associated invertebrate communities, a transplantation experiment was conducted along a gradient of estuarine acidification in the Hastings Estuary, NSW, Australia. Sites were the same as those used by Glaspie and Seitz (2017) and are briefly described here. Collection sites were chosen based on distance from a tidal gate draining acidified waters from acid sulfate soils, which resulted in a gradient of mean $\mathrm{pH}$ and alkalinity among sites (Table 1; Tulau 1999). Each site contained fringing Avicennia marina mangroves, with Sydney rock oysters Saccostrea glomerata growing on the pneumatophores and trunks of the mangroves.

The $\mathrm{pH}$, temperature, and salinity of study sites were measured once at high tide, once at low tide, and three times at the time of oyster collection using a Horiba U-50 series multiparameter water quality meter (Horiba Instruments, Irvine, CA). Dissolved oxygen was measured with the water quality meter once at low tide. Four water samples from each site were brought back to the laboratory, and alkalinity was measured using an Aquarium Pharmaceuticals carbonate hardness test kit (Aquarium Pharmaceuticals, Chalfon, PA).

The two sites closest to the tidal gate had high exposure to acidification: these sites had at least one $\mathrm{pH}$ reading of 5.5 or less, orange-red sediment indicative of acid sulfate soils, and a history of $\mathrm{pH}$ readings as low as 2 during previous studies in the area (Tulau 1999, Amaral et al. 2011, 2012a, Dove \& Sammut 2013). The two sites farther away from the tidal gate experienced moderate or low exposure to chronic acidification: they were at least $3 \mathrm{~km}$ from flood gates, had all $\mathrm{pH}$ readings between 6.3 and 6.8, were free of sediment discoloration, and were in stretches of the estuary with low exposure to acid sulfate soil (Table 1; Tulau 1999). No nonacidified sites exist in the Hastings Estuary, so a nonacidified control was not possible for this study.

In July 2014, 24 clumps of live oysters were collected from mangrove pneumatophores at the moderate-exposure site and the low-exposure site. Each clump was of 14-40 cm length, $7.5-23.5 \mathrm{~cm}$ width, and contained oysters $11.1-70.7 \mathrm{~mm}$ in shell height. Six replicate clumps per site were retained to measure the community composition of invertebrates before transplantation (source site control, Fig. 1). Six clumps were transplanted back to their original site as a control for the effects of transplantation on oysters and their communities (transplantation control, Fig. 1). Finally, to test the effects of episodic exposure to acidified conditions on oyster communities, six replicate clumps were transplanted from the moderate-exposure and low-exposure sites to each of the two high-exposure sites (Fig. 1). Oysters and their associated communities were randomly assigned to the transplantation treatments and controls and were returned to the field within 24-h of collection. Before transplantation, the number of dead (i.e., gaping) and live oysters in each clump were counted. Transplanted oysters were secured with plastic ties to stakes set 1 $\mathrm{m}$ apart along the shoreline in the intertidal zone, with randomized positions. After a 2-wk period, clumps of oysters, and associated invertebrates, were collected, identified, and enumerated. The dead oysters remaining in each clump were counted on collection. Oyster proportional mortality was calculated as the number of new dead (dead at the end of the experiment minus dead at the beginning) divided by the number of live oysters initially in the clump.

Oyster clumps with associated invertebrates were frozen until processing. Freezing and subsequent thawing may have resulted in disintegration of some soft-bodied phyla; however, logistical challenges prevented other fixation and preservation

TABLE 1.

Environmental data for the four oyster source and destination sites in the Hastings Estuary, NSW, Australia, during July 2014.

\begin{tabular}{|c|c|c|c|c|c|c|c|c|}
\hline Site & Latitude & Longitude & pH range & Alkalinity (dKh) & Salinity & Temperature $\left({ }^{\circ} \mathbf{C}\right)$ & Dissolved oxygen $\left(\mathrm{mg} \mathrm{L}^{-1}\right)$ & Distance $(\mathbf{k m})$ \\
\hline High exposure 1 & -31.4045 & 152.8522 & $5.00-6.58$ & $7.8(0.5)$ & $32.1(1.6)$ & $15.01(1.06)$ & 6.56 & 2.01 \\
\hline High exposure 2 & -31.3991 & 152.8527 & $5.50-6.63$ & $7.5(0.6)$ & $31.8(1.3)$ & $16.24(0.04)$ & 8.45 & 2.76 \\
\hline Mod. exposure & -31.4117 & 152.8625 & $6.36-6.80$ & $8.3(0.5)$ & $33.9(0.2)$ & $17.21(0.04)$ & 4.96 & 3.54 \\
\hline Low exposure & -31.4099 & 152.9031 & $6.43-6.80$ & $9.3(0.5)$ & $35.4(0.4)$ & $18.18(0.02)$ & 8.63 & 8.24 \\
\hline
\end{tabular}

Adapted from Glaspie and Seitz (2017). Means and SD are shown for alkalinity $(n=4)$, salinity $(n=5)$, and temperature $(n=5)$. Also shown are dissolved oxygen $(n=1)$ and distance from tidal gate $(n=1)$. 


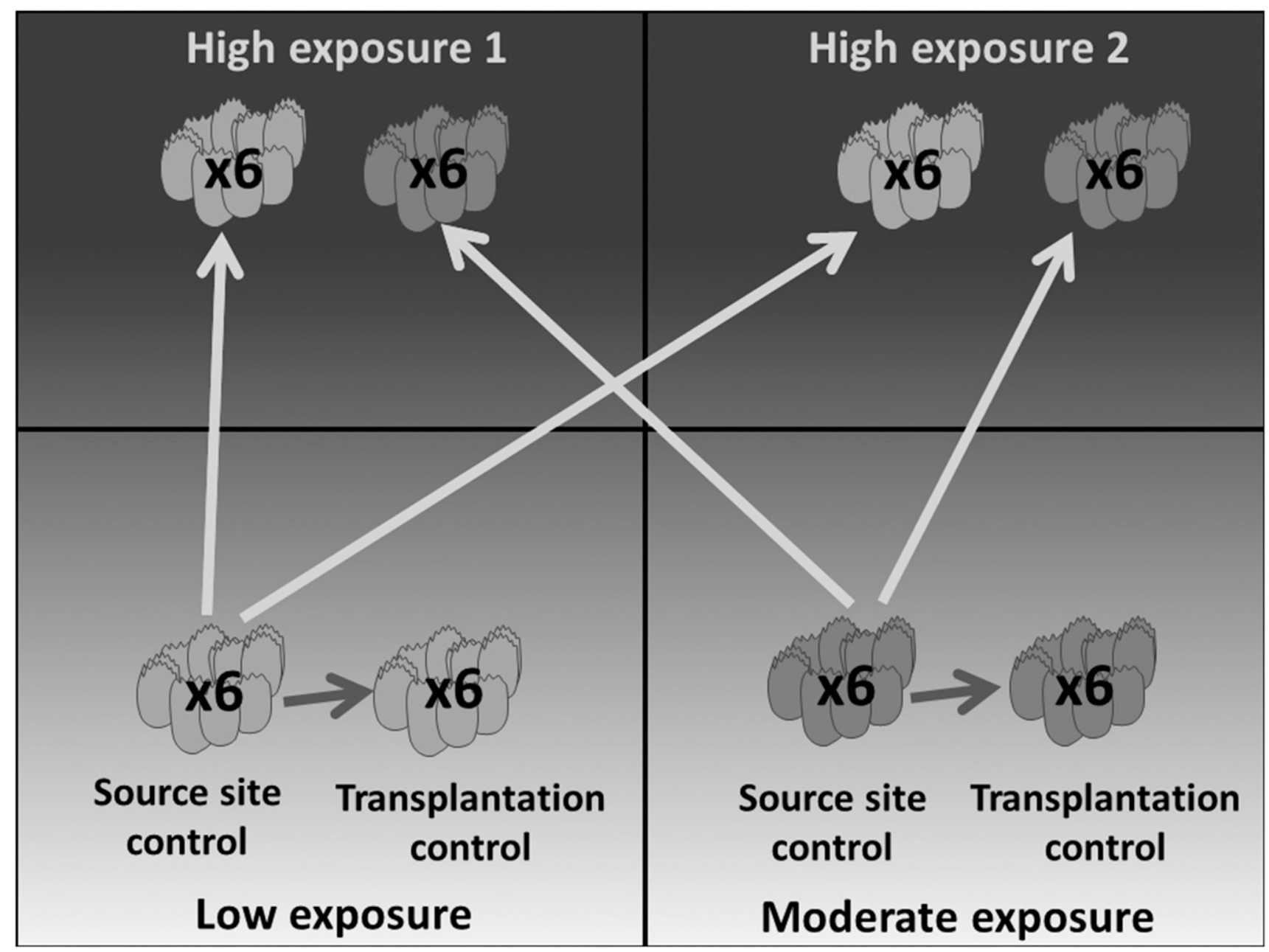

Figure 1. Design of transplant experiment to determine the effect of exposure to acidified water on oyster-associated epifaunal communities. Oysters came from source sites with either of two chronic exposure regimes (low or moderate exposure to chronic acidification) and were subjected to either episodic acidification (two sites with high exposure to acidification, pooled for analysis) or control conditions (two controls, pooled for analysis).

methods, and freezing is a common method of preserving oyster reef samples (Lejart \& Hily 2011). On defrosting, oyster clumps were disarticulated and rinsed over a 1-mm sieve to separate organisms on the shell exterior and within the shell matrix from the oysters. Organisms retained on the sieve were identified to the lowest taxonomic unit (species for snails and mussels, and genus or family for worms and amphipods) and counted. Taxa are referred to as operational taxonomic units (OTU) in the following analyses. Species diversity was calculated as OTU diversity and used the formula for Gini-Simpson diversity index:

$$
1-\sum_{i=1}^{R} p_{i}{ }^{2}
$$

where $p_{i}=$ the proportional abundance of the $i$ th species.

\section{Statistical Analysis}

All analysis of variance (ANOVA) tests were structured as two-way designs with the following factors: chronic acidification regime (two levels, fixed: moderate exposure and low exposure), and episodic exposure (transplantation) treatment (four levels, fixed: high-exposure site 1 , high-exposure site 2 , transplantation control, and source site control; $n=6$ ). There were two preplanned contrasts using Tukey's honestly significant difference post hoc tests: one assessed if high-exposure site 1 and highexposure site 2 were significantly different, and the other assessed if the transplantation and source site controls were significantly different, to determine if they could be pooled into two levels (fixed: acidified and control; $n=12$ ). There were no significant differences (at the $\alpha=0.25$ level) between (1) high-exposure sites 1 and 2 or (2) transplantation and source site controls for any response variables (oyster mortality, diversity, richness, total organism abundance, or community composition), so all highexposure site samples (high-exposure sites 1 and 2) were pooled for analyses as a single acidified treatment, and all controls (transplantation and source site controls) were pooled for analysis as a single control treatment (Underwood 1997). These analyses were completed in R statistical software (R Core Team 2017).

Invertebrate abundance data were analyzed using PRIMER 6 with PERMANOVA+. Analyses used Bray-Curtis dissimilarity matrices (Bray \& Curtis 1957) calculated from square-root transformed data. A distance-based permutational multivariate analysis of variance (PERMANOVA) was performed to determine the effects of chronic acidification regime and episodic exposure treatment on patterns in oyster-associated epifaunal 
communities (Anderson 2001). To determine if oyster mortality data were correlated with patterns in abundance of associated epifaunal species, a RELATE test for matched resemblance matrices was performed. The relationship between oyster mortality and all of the most commonly encountered OTUs (more than 30 individuals collected) was examined using linear models on square-root transformed abundance data.

A similarity percentage procedure was used to identify the specific OTU that contributed to observed differences between chronic and episodic exposure treatments (Clarke 1993). For the five OTU contributing the most to dissimilarities between chronic and episodic exposure treatments, ANOVA was used to assess differences in abundance. Differences in diversity, richness, and total abundance between chronic exposure regimes and episodic exposure treatments were also analyzed using ANOVA. Normality and homogeneity of variance were assessed for each ANOVA and are not mentioned unless transformations were necessary to meet assumptions.

\section{RESULTS}

Alkalinity differed significantly between the low-exposure and moderate-exposure sites $\left[t_{6}=-2.83, P=0.03\right.$; Table 1; Fig. A1(A)]. There was no significant difference in $\mathrm{pH}$ between the low-exposure and moderate-exposure sites throughout the course of the study $\left[t_{7}=-0.15, P=0.89\right.$; Table 1; Fig. A1 (B)]. This is likely because the study occurred during a relatively dry period, with $0.38 \mathrm{~mm}$ precipitation recorded at the nearby Port Macquarie Airport for the study period July 28th through August $11^{\text {th }}, 2014$ (National Climate Data Center), and these sites may only experience extreme acidification during a runoff event.

The Gini-Simpson diversity index was significantly lower for oyster communities exposed to episodic acidification, as compared with communities exposed to control conditions (Table 2; Fig. 2); however, there was no difference in diversity for oyster communities sourced from different chronic acidification regimes (Table 2). Species richness (means \pm SD: $5.04 \pm 2.12$ acidified, $5.54 \pm 1.47$ control) and total organism abundance (means $\pm \mathrm{SD}$ : $15.17 \pm 8.79$ acidified, $17.13 \pm 5.93$ control) were not significantly different for oyster communities from different chronic exposure regimes (moderate exposure or low exposure) or different episodic acidification treatments (acidified versus control; Table 2). There was a significant effect of both chronic and episodic acidification on epifaunal community composition (Table 3 ).

Oyster mortality was minimal and ranged from $0 \%$ to $20 \%$ over the 2-wk period, with an average mortality rate of $3.1 \%$ $(\mathrm{SE}=0.9 \%)$. Patterns in epifaunal community composition were significantly correlated with patterns in oyster mortality (Rho $=0.181, P=0.027$ ). Of the linear models examining the relationship between oyster mortality and abundance of the five most common OTU (the limpet Patelloida mimula, spionid polychaetes, the snail Bembicium auratum, the mussel Xenostrobus securis, and syllid polychaetes), two showed a significant impact of oyster mortality on species abundance. Both $X$. securis and $P$. mimula abundances were negatively correlated with oyster mortality (Fig. 3). There were no significant effects of chronic acidification regime $\left(F_{1,32}=0.56, P=0.46\right)$ or exposure to episodic acidification $\left(F_{1,33}=1.06, P=0.31\right)$ on oyster mortality (Fig. 4).

In total, 23 OTU were collected, including several groups of gastropods, bivalves, crustaceans, and polychaetes. Oysters
TABLE 2.

Results of a two-way ANOVA examining the effect of chronic acidification regime of source site (chronic; low exposure or moderate exposure to chronic acidification) and episodic acidification treatment (episodic; acidic versus control) on Gini-Simpson diversity index, species richness (both calculated for OTU), and total organism abundance.

\begin{tabular}{lrccc}
\hline \hline & df & Mean square & $\boldsymbol{F}$ value & $\boldsymbol{P}$ value \\
\hline Diversity & & & & \\
$\quad$ Chronic & 1 & 0.02 & 0.96 & 0.33 \\
Episodic & 1 & 0.09 & 4.36 & $\mathbf{0 . 0 4}$ \\
Chronic $\times$ episodic & 1 & $<0.001$ & $<0.001$ & 0.99 \\
$\quad$ Residuals & 44 & 0.02 & - & - \\
Richness & & & & \\
Chronic & 1 & 3.00 & 0.88 & 0.35 \\
Episodic & 1 & 3.00 & 0.88 & 0.35 \\
Chronic $\times$ episodic & 1 & 0.08 & 0.02 & 0.87 \\
Residuals & 44 & 3.41 & - & - \\
Total abundance (quartic-root transformed) & & \\
Chronic & 1 & $<0.001$ & $<0.001$ & 0.99 \\
Episodic & 1 & 0.09 & 1.63 & 0.21 \\
Chronic $\times$ episodic & 1 & 0.04 & 0.67 & 0.42 \\
Residuals & 44 & 2.36 & - & - \\
\hline
\end{tabular}

Significant $P$ values (at $\alpha=0.05$ ) are bolded.

exposed to a 2-wk episode of acidification contained 21 OTU, including some that were not found on control oysters (the clams Tapes conspersus and Irus crenatus; the snail Bankivia fasciata; and the polychaete families Serpulidae and Lumrineridae). Oysters that

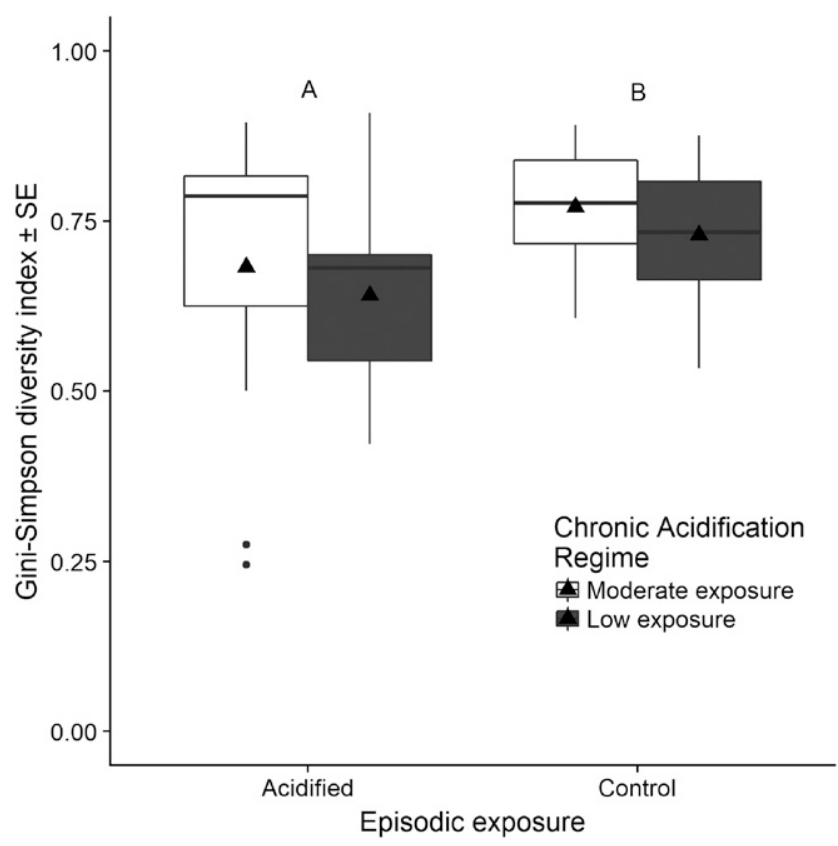

Figure 2. Gini-Simpson species diversity index for oyster-associated epifaunal communities sourced from different chronic exposure regimes (moderate or low exposure to chronic acidification, indicated by shading) and exposed to different episodic acidification treatments (acidified and control). Boxes extend from the first to third quartile with a horizontal line at the median and a triangle symbol at the mean. Whiskers extend from the lowest data point that is still within 1.5 interquartile range (IQR) of the lower quartile to the highest data point still within 1.5 IQR of the upper quartile. Letters indicate significant differences in means at $\alpha=0.05$. 
TABLE 3.

Type I SS PERMANOVA table indicating the effect of chronic acidification regime of source site (chronic; low exposure or moderate exposure to chronic acidification) and episodic acidification treatment (episodic; acidic versus control) on oyster-associated epifaunal communities.

\begin{tabular}{lrrcc}
\hline \hline \multicolumn{1}{c}{ Source } & df & \multicolumn{1}{c}{ MS } & Pseudo- $\boldsymbol{F}$ & $\boldsymbol{P}$ value \\
\hline Chronic & 1 & 3870.3 & 3.21 & $\mathbf{0 . 0 0 2}$ \\
Episodic & 1 & 2634.6 & 2.18 & $\mathbf{0 . 0 4}$ \\
Chronic $\times$ episodic & 1 & 451.5 & 0.38 & 0.86 \\
Res & 44 & 1207.2 & - & - \\
\hline
\end{tabular}

Significant $P$ values (at $\alpha=0.05$ ) are bolded.

were not exposed to the episodic acidification, but instead to control conditions, contained 18 OTU, including two species that were never found on oysters transplanted to acidified conditions (the crab Pilumnopeus spp. and the snail Bedeva paivae). The five most common OTU collected in both episodic acidification treatments (acidified and control) were the limpet Patelloida mimula (total collected 165 acidified, 155 controls), spionid polychaetes (total collected 63 acidified, 67 controls), syllid polychaetes (total collected 26 acidified, 17 controls), the mussel Xenostrobus securis (total collected 17 acidified, 29 controls), and the snail Bembicium auratum (total collected 34 acidified, 75 controls). The same five OTU contributed the most to dissimilarities between communities from different chronic acidification regimes and between communities exposed to different episodic acidification treatments, together resulting in $58.26 \%$ of the dissimilarity between chronic exposure source sites and $57.12 \%$ of the dissimilarity between acidic and control groups (Table 4).

Abundance differed significantly between chronic acidification regimes for three OTU. These were Xenostrobus securis, which were more abundant at the moderate-exposure site (ANOVA; square-root transformed data; $F_{1,44}=7.98, P=0.01$ ); and Spionidae $\left(F_{1,44}=4.82, P=0.03\right)$ and Syllidae (square-root transformed; $F_{1,44}=7.48, P=0.01$; Fig. $5 \mathrm{~A}-\mathrm{C}$ ), which were more abundant at the low-exposure site. Two OTU, X. securis and Bembicium auratum, showed a significant difference in abundance between episodic acidification treatments. Both $X$. securis $\left(F_{1,44}=4.61, P=0.04\right.$; Fig. 5 C) and B. auratum $\left(F_{1,44}=\right.$ 5.56, $P=0.02$; Fig. 5D) were less abundant on oyster clumps exposed to episodic acidification than on those at control sites.

\section{DISCUSSION}

The intensity and duration of acidification largely determines how species cope with acidified water. As a first defense against acidification, some organisms, such as polychaetes, are capable of acclimating to acidification and can survive in low pH waters without changes to metabolism (Calosi et al. 2013). This strategy may prevent some organisms from adverse effects of chronic, low levels of acidification. Bivalves may dissolve shell material to buffer $\mathrm{pH}$ in their tissues; however, this mechanism may be unable to prevent tissue damage when acidification occurs over a period of months (Michaelidis et al. 2005). If organisms are unable to acclimate, they may reduce metabolic rates to survive episodes of extreme acidification (Proum et al. 2017). A reduced metabolism prevents tissue damage and conserves energy (Strahl et al. 2011). Finally, if acidification is too extreme or prolonged, organisms may exhibit avoidance behavior, as seen in some gastropods (Alfaro 2007, Marshall et al. 2008, Amaral et al. 2011, 2014). Oysterassociated communities in estuaries acidified by acid sulfate soils likely use multiple strategies to minimize consequences of chronic and episodic low $\mathrm{pH}$; however, this study provides evidence that acidification may be associated with loss (either through mortality or emigration) of some species.

Despite the exposure of this estuarine community to acid sulfate soil runoff for generations, episodic acidification still resulted in a decrease in epifaunal diversity as compared with the control, highlighting the consequences of acidification even in coastal systems where biota experience frequent and often extreme fluctuations in $\mathrm{pH}$ (Widdicombe \& Spicer 2008). Coastal species that experience extreme $\mathrm{pH}$ on daily or seasonal cycles are expected to be less vulnerable to acidification than species that are adapted to more constant environments, such as the open ocean or polar regions (Whiteley 2011). Despite this, acidification due to anthropogenic forcing (in this case, land-use changes) can have impacts on diversity through species-specific vulnerabilities related to acidification-induced changes in calcification (Gazeau et al. 2007), settlement (Clements et al. 2016), or interactions with other species (Bibby et al. 2007, Dodd et al. 2015).

In particular, the mobile gastropod Bembicium auratum was negatively impacted by episodic acidification. The present study was not designed to determine whether $B$. auratum was lost from the oyster communities because of mortality or migration; however, it is likely that behavioral adaptations resulted in migration and reduced abundances of $B$. auratum at acidified sites. During high tide, B. auratum will migrate up mangrove trunks or pneumatophores only to return to oyster communities once the tide has receded (Alfaro 2007, Marshall et al. 2008, Amaral et al. 2011, 2014). Displacement of gastropods in regions experiencing increased episodic acidification will likely reduce the diversity of primary producers on the surfaces of oyster reefs because of the absence of grazing (Brönmark 1989, Mccormick \& Stevenson 2007). Because the present study did not characterize the diversity of primary producers on oyster reefs, the effect of acidification-induced loss of grazers on algal composition remains an area where future research is needed.

Similar to Bembicium auratum, the mussel Xenostrobus securis also exhibited significant declines in abundance on exposure to episodic acidification as compared with the control. Mussels also had the highest abundances in the site with moderate exposure to chronic acidification. There is no evidence that $X$. securis is especially sensitive or tolerant to a gradient in acidification (Corfield 2000). It is possible that in the Hastings Estuary, X. securis is most competitive in a scenario of intermediate disturbance (Sousa 1979). In this scenario, occasional episodes of moderate acidification create an opportunity for mussels to exploit newly available space or the temporary absence of molluscan grazers, which can prevent recruitment by encrusting species such as barnacles (Buschbaum 2000).

Spionid and syllid worms may be sensitive to source site differences in acidification, because they had the highest abundances in the source site that was exposed to low levels of chronic acidification. Some polychaetes, especially tube builders, are expected to be sensitive to acidification (Corfield 2000, Kroeker et al. 2011). In the present study, polychaetes 

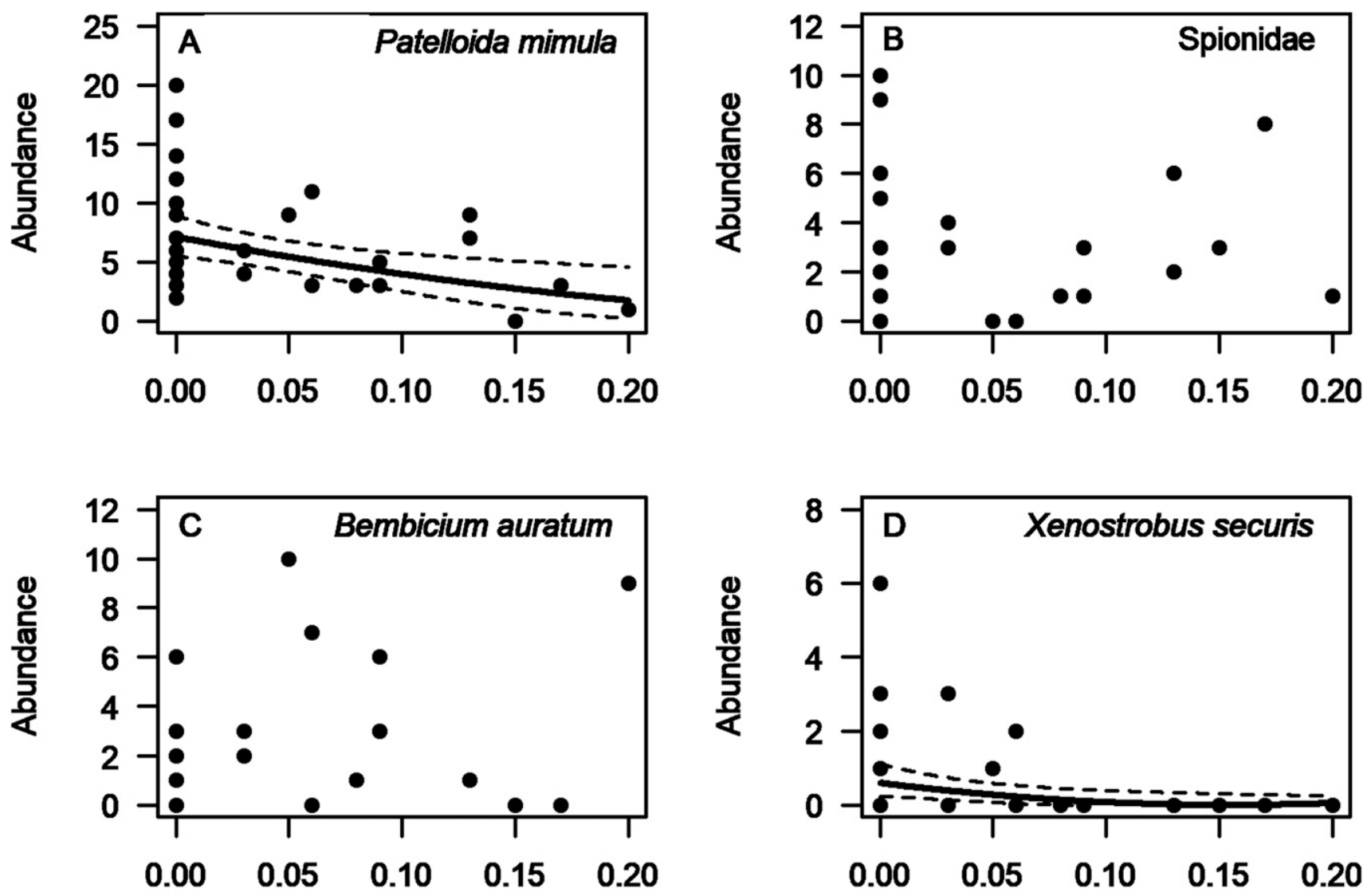

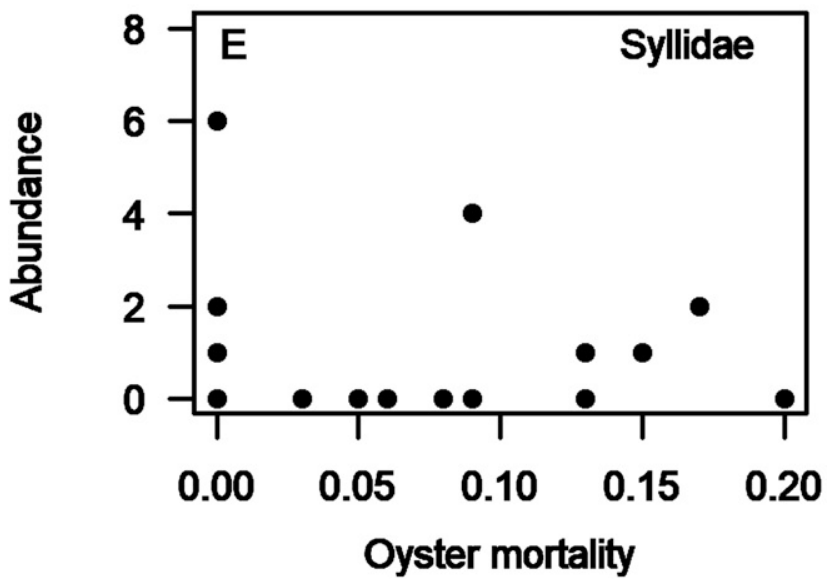

were not lost on transplantation to episodic acidified conditions, likely because many adult polychaetes have the capacity to acclimate or adapt to low $\mathrm{pH}$ (Calosi et al. 2013). By contrast, polychaete larvae are sensitive to low pH (Lewis et al. 2012, Campbell et al. 2014), a sensitivity that, over the scale of months to years, may have resulted in lower polychaete abundance in the more-acidic control site.

Whereas the Sydney rock oyster Saccostrea glomerata in this acidified estuary appeared well adapted to naturally occurring acidification events and little mortality was evident, when oyster mortality did occur, epifaunal community composition changed. The loss of oysters may impact oyster-associated communities by reducing the abundance of sessile species. In the present study, two species with relatively low mobility (the mussel Xenostrobus securis and the limpet Patelloida mimula) were negatively associated with oyster mortality. Disturbances, such as trawling, that reorganize habitat elements tend to decrease density of sessile epifauna by displacing or damaging them (Freese et al. 1999). Epifaunal community restructuring also occurs when oysters die, even when they are not physically removed from the reef. A study examining the impact of disease-driven oyster mortality on oyster-associated community composition in NSW estuaries found that as oyster mortality increased, epifaunal species richness decreased (Summerhayes et al. 2009). 


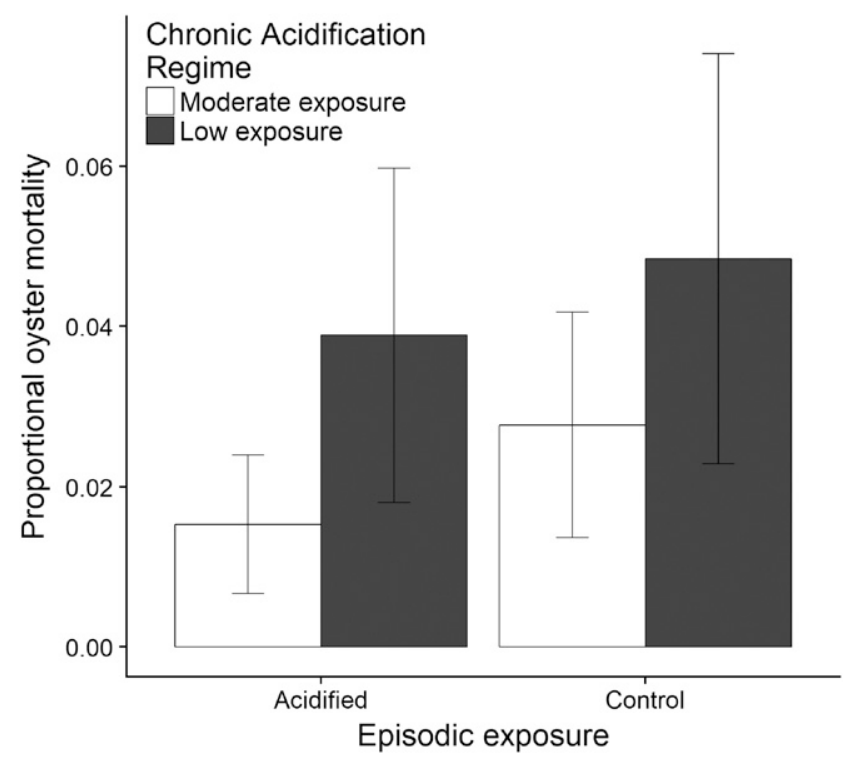

Figure 4. Means ( $\pm 1 \mathrm{SE}$ ) for proportional mortality of oysters sourced from different chronic exposure regimes (moderate or low exposure to chronic acidification, indicated by shading) and exposed to different episodic acidification treatments (acidified and control).

Temporal scale is an important consideration in determining the impacts of acidification on communities of estuarine organisms. Prior exposure to some stressors may precondition organisms to be more resistant or resilient to stress in the future (Rapport \& Whitford 1999). Despite this, there was no evidence for synergistic or antagonistic effects between chronic exposure and episodic exposure; that is, exposure to chronic acidification did not increase resistance to an episode of acidification. Instead, episodic acidification decreased species diversity and resulted in declines in a dominant grazer, the snail Bembicium auratum. Chronic acidification resulted in decreased abundance of spionid and syllid polychaete worms. Episodes of acidification may have substantial impacts on the food web that are additive to impacts of chronic exposure (Rosemond \& Reice 1992); however, this study only considered a 2 -wk period of extreme acidification. The frequency and degree of acidification are crucial to population resistance, and future work should examine community response to a variety of events with different durations and intensities to fully understand the impact of acid sulfate soil acidification on oyster-associated epifauna.

Indices of estuarine acidification that rely on communities of organisms may assist in the monitoring and restoration of these systems. Such indices have been used with success to study eutrophication or pollution in freshwater (Kelly 1998), estuarine (Weisberg et al. 1997), and marine systems (Karydis \& Tsirtsis 1996). The goal of index development is to relate changes in the environment to taxonomic diversity or the abundance of a suite of indicator species that will allow ecosystem managers a scientifically sound and logistically feasible means to see the impacts of management decisions. This study provides possible indicator species that could be used to look at acidification in the Hastings Estuary and other coastal systems in NSW, but the results may not be relevant to coastal systems without acid sulfate soils. Areas impacted by acid sulfate soils exhibit lower salinity, lower alkalinity, higher concentration of toxic metals, and higher turbidity than areas that are not impacted (Amaral et al. 2011, Nath et al. 2013, Glaspie \& Seitz 2017). This study was not designed to distinguish between the impacts of these correlated environmental

TABLE 4.

Similarity percentage analysis results indicating OTU contributing to differences between chronic acidification regime at source sites (low exposure or moderate exposure to chronic acidification) and between treatments (acidified and control). Shown are abundances, average dissimilarity (Av. Diss), dissimilarity over SD (Diss/SD), percent contribution (Contrib\%), and cumulative percent contribution (Cum.\%).

\begin{tabular}{|c|c|c|c|c|c|c|}
\hline \multicolumn{7}{|c|}{ Chronic acidification } \\
\hline OTU & Moderate-exposure abundance & Low-exposure abundance & Av. Diss & Diss/SD & Contrib\% & Cum.\% \\
\hline Spionidae & 1.11 & 1.61 & 6.75 & 1.29 & 13.71 & 13.71 \\
\hline Bembicium auratum & 1.20 & 1.17 & 6.23 & 1.13 & 12.66 & 26.38 \\
\hline Patelloida mimula & 2.56 & 2.35 & 5.61 & 1.13 & 11.40 & 37.77 \\
\hline Syllidae & 0.33 & 0.88 & 5.34 & 1.27 & 10.85 & 48.62 \\
\hline Xenostrobus securis & 0.93 & 0.40 & 4.75 & 1.16 & 9.64 & 58.26 \\
\hline Gammarus spp. & 0.56 & 0.36 & 3.70 & 0.95 & 7.51 & 65.77 \\
\hline Corophium spp. & 0.18 & 0.35 & 2.59 & 0.76 & 5.27 & 71.04 \\
\hline Sesarma spp. & 0.27 & 0.31 & 2.37 & 0.76 & 4.82 & 75.86 \\
\hline \multicolumn{7}{|c|}{ Episodic acidification } \\
\hline OTU & Acidified treatment abundance & Control abundance & Av. Diss & Diss/SD & Contrib\% & Cum. $\%$ \\
\hline B. auratum & 0.86 & 1.51 & 7.20 & 1.23 & 14.97 & 14.97 \\
\hline Spionidae & 1.36 & 1.36 & 6.29 & 1.25 & 13.09 & 28.05 \\
\hline P. mimula & 2.48 & 2.43 & 5.58 & 1.16 & 11.59 & 39.65 \\
\hline X. securis & 0.46 & 0.87 & 4.59 & 1.16 & 9.54 & 49.19 \\
\hline Syllidae & 0.71 & 0.50 & 3.81 & 0.94 & 7.93 & 57.12 \\
\hline Gammarus spp. & 0.43 & 0.49 & 3.65 & 0.94 & 7.60 & 64.72 \\
\hline Sesarma spp. & 0.18 & 0.39 & 2.78 & 0.81 & 5.79 & 70.51 \\
\hline Corophium spp. & 0.23 & 0.31 & 2.54 & 0.74 & 5.27 & 75.78 \\
\hline
\end{tabular}



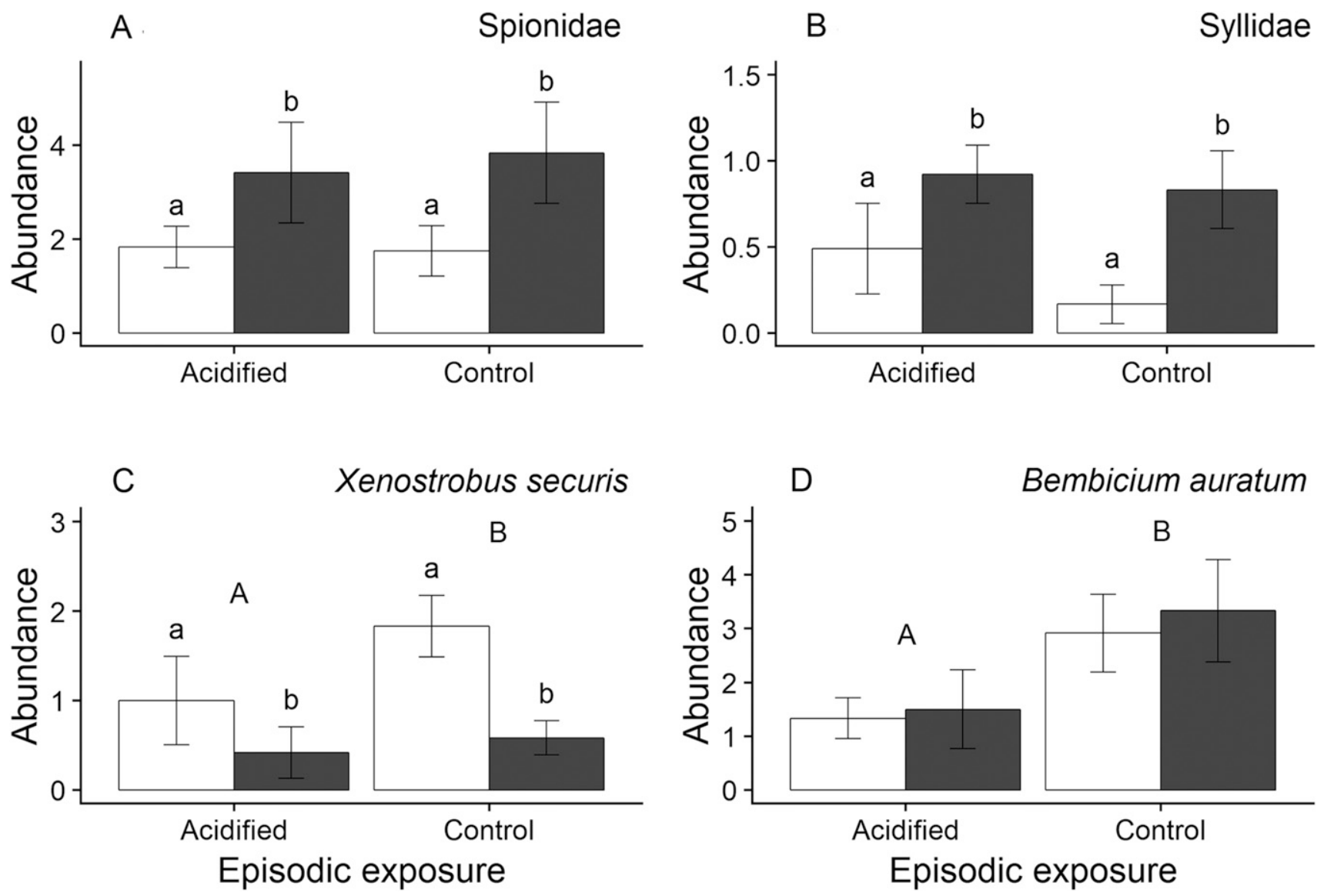

Figure 5. Means ( \pm 1 SE) for abundance of (A) Spionidae, (B) Syllidae (square-root transformed), (C) Xenostrobus securis, and (D) Bembicium auratum on oysters sourced from different chronic exposure regimes (moderate exposure to chronic acidification in white bars or low exposure to chronic acidification in gray bars) and exposed to different episodic acidification treatments (acidified and control). Letters indicate significant differences at $\alpha=0.05$.

stressors, but instead to address the collective impact of these stressors on oyster mortality and epifaunal community composition. Other acidified systems may not experience this combination of environmental stressors, any of which could be responsible for the observed trends in epifaunal diversity.

\section{CONCLUSIONS}

Acidification on different timescales (chronic or episodic) had different impacts on communities of epifauna associated with the foundation oyster species Saccostrea glomerata in the Hastings Estuary, which experiences acid sulfate soil runoff. Episodic acidification was associated with decreased diversity of oyster-associated epifaunal communities, as compared with the control. Syllid and spionid polychaetes were less abundant on oysters exposed to chronic acidification, as compared with those with low exposure. The gastropod Bembicium auratum and the mussel Xenostrobus securis were negatively impacted by episodic ( $2 \mathrm{wk}$ ) acidification typical of an acid sulfate soil runoff event. Oyster mortality did not change significantly with episodic or chronic acidification, demonstrating the capacity of $S$. glomerata to withstand environmental change; however, trends in epifaunal community composition were correlated with trends in oyster mortality, especially for structure-associated species with low mobility such as mussels and limpets, which were negatively associated with oyster mortality. Therefore, it could be suggested that the fate of this marine community is closely tied to that of its foundation species. Because oysters and many other habitat-forming species such as seagrasses, corals, and kelp are at risk due to anthropogenic stressors, the degree to which habitat-forming species and their associated communities respond similarly or differentially to the effects of environmental stressors is of concern. Resistance to acidification in oyster-associated species in the Hastings Estuary may depend on the ability of oysters to persist in the face of environmental fluctuations or degradation.

\section{ACKNOWLEDGMENTS}

The authors gratefully acknowledge the assistance given by Calvin Glaspie, Dr. Joseph Kenworthy, James Chan, Lauren Fletcher, Mary Gerloff, Drew Munro, and Ju-Deh Tan in data collection and field support. Dr. Melanie Bishop, Julia Moriarty, Britt Dean, Megan Wood, and Amanda Knobloch provided valuable comments on an earlier draft of this manuscript. Dr. Melanie Bishop also provided logistical support for the completion of this research. This material is based on the work supported by the National Science Foundation under Grant Numbers 1414746 and HRD-1107147. This paper is contribution number 3735 from the Virginia Institute of Marine Science, College of William \& Mary. 


\section{LITERATURE CITED}

Alfaro, A. C. 2007. Migration and trail affinity of snails, Littoraria scabra, on mangrove trees of Nananu-i-ra, Fiji Islands. Mar. Freshwat. Behav. Physiol. 40:247-255.

Amaral, V., H. N. Cabral \& M. J. Bishop. 2011. Resistance among wild invertebrate populations to recurrent estuarine acidification. Estuar. Coast. Shelf Sci. 93:460-467.

Amaral, V., H. N. Cabral \& M. J. Bishop. 2012a. Moderate acidification affects growth but not survival of 6-month-old oysters. Aquat. Ecol. 46:119-127.

Amaral, V., H. N. Cabral \& M. J. Bishop. 2012b. Effects of estuarine acidification on predator-prey interactions. Mar. Ecol. Prog. Ser. 445:117-127.

Amaral, V., H. N. Cabral \& M. J. Bishop. 2014. Prior exposure influences the behavioural avoidance by an intertidal gastropod, Bembicium auratum, of acidified waters. Estuar. Coast. Shelf Sci. 136:82-90.

Anderson, M. J. 2001. A new method for non-parametric multivariate analysis of variance. Austral. Ecology 26:32-46.

Bibby, R., P. Cleall-Harding, S. Rundle, S. Widdicombe \& J. Spicer. 2007. Ocean acidification disrupts induced defences in the intertidal gastropod Littorina littorea. Biol. Lett. 3:699-701.

Bray, J. R. \& J. T. Curtis. 1957. An ordination of the upland forest communities of southern Wisconsin. Ecological Monographs 27:325-349.

Brönmark, C. 1989. Interactions between epiphytes, macrophytes and freshwater snails: a review. J. Molluscan Stud. 55:299-311.

Bulling, M. T., N. Hicks, L. Murray, D. M. Paterson, D. Raffaelli, P. C. L. White \& M. Solan. 2010. Marine biodiversity-ecosystem functions under uncertain environmental futures. Philos. Trans. $R$. Soc. Lond. B Biol. Sci. 365:2107-2116.

Buschbaum, C. 2000. Direct and indirect effects of Littorina littorea (L.) on barnacles growing on mussel beds in the Wadden Sea. Hydrobiologia 440:119-128.

Cai, W. J., W. J. Huang, G. W. Luther, D. Pierrot, M. Li, J. Testa, M. Xue, A. Joesoef, R. Mann, J. Brodeur, Y. Y. Xu, B. Chen, N. Hussain, G. G. Waldbusser, J. Cornwell \& W. M. Kemp. 2017. Redox reactions and weak buffering capacity lead to acidification in the Chesapeake Bay. Nat. Commun. 8:1-12.

Calosi, P., S. P. Rastrick, C. Lombardi, H. J. de Guzman, L. Davidson, M. Jahnke, A. Giangrande, J. D. Hardege, A. Schulze, J. I. Spicer \& M. C. Gambi. 2013. Adaptation and acclimatization to ocean acidification in marine ectotherms: an in situ transplant experiment with polychaetes at a shallow $\mathrm{CO}_{2}$ vent system. Philos. Trans. R. Soc. Lond. B Biol. Sci. 368:1-15.

Campbell, A. L., S. Mangan, R. P. Ellis \& C. Lewis. 2014. Ocean acidification increases copper toxicity to the early life history stages of the polychaete in artificial seawater. Environ. Sci. Technol. 48:97459753.

Clarke, K. R. 1993. Non-parametric multivariate analyses of changes in community structure. Austral. Ecology 18:117-143.

Clements, J. C., K. D. Woodard \& H. L. Hunt. 2016. Porewater acidification alters the burrowing behavior and post-settlement dispersal of juvenile soft-shell clams (Mya arenaria). J. Exp. Mar. Biol. Ecol. 477:103-111.

Cook, F. J., W. Hicks, E. A. Gardner, G. D. Carlin \& D. W. Froggatt. 2000. Export of acidity in drainage water from acid sulphate soils. Mar. Pollut. Bull. 41:319-326.

Corfield, J. 2000. The effects of acid sulphate run-off on a subtidal estuarine macrobenthic community in the Richmond River, NSW, Australia. ICES J. Mar. Sci. 57:1517-1523.

Dent, D. L. \& L. J. Pons. 1995. A world perspective on acid sulphate soils. Geoderma 68:225.

Dodd, L. F., J. H. Grabowski, M. F. Piehler, I. Westfield, J. B. Ries \& L. F. Dodd. 2015. Ocean acidification impairs crab foraging behaviour. Proc. Biol. Sci. 282:20150333.
Dove, M. C. \& J. Sammut. 2013. Acid sulfate soil induced acidification of estuarine areas used for the production of Sydney rock oysters, Saccostrea glomerata. J. Water Resource Prot. 5:320-335.

Duarte, C. M., W. C. Dennison, R. J. W. Orth \& T. J. B. Carruthers. 2008. The charisma of coastal ecosystems: addressing the imbalance. Estuar. Coasts 31:233-238.

Feely, R. A., S. R. Alin, J. Newton, C. L. Sabine, M. Warner, A. Devol, C. Krembs \& C. Maloy. 2010. The combined effects of ocean acidification, mixing, and respiration on $\mathrm{pH}$ and carbonate saturation in an urbanized estuary. Estuar. Coast. Shelf Sci. 88:442-449.

Freese, L., P. J. Auster, J. Heifetz \& B. L. Wing. 1999. Effects of trawling on seafloor habitat and associated invertebrate taxa in the Gulf of Alaska. Mar. Ecol. Prog. Ser. 182:119-126.

Gazeau, F., C. Quiblier, J. M. Jansen, J. P. Gattuso, J. J. Middelburg \& C. H. R. Heip. 2007. Impact of elevated $\mathrm{CO}_{2}$ on shellfish calcification. Geophys. Res. Lett. 34:1-5.

Gedan, K. B. \& M. D. Bertness. 2010. How will warming affect the salt marsh foundation species Spartina patens and its ecological role? Oecologia 164:479-487.

Glaspie, C. N. \& R. D. Seitz. 2017. Multiple stressors associated with acid sulfate soil effluent influence mud crab Scylla serrata predation on Sydney rock oysters Saccostrea glomerata. Mar. Freshw. Res. 68:743-751.

Gonzalez, A. \& M. Loreau. 2009. The causes and consequences of compensatory dynamics in ecological communities. Annu. Rev. Ecol. Evol. Syst. 40:393-414.

Gutiérrez, J. L., C. G. Jones, D. L. Strayer \& O. Iribarne. 2003. Mollusks as ecosystem engineers: the role of shell production in aquatic habitats. Oikos 101:79-90.

Howland, R. J. M., A. D. Tappin, R. J. Uncles, D. H. Plummer \& N. J. Bloomer. 2000. Distributions and seasonal variability of $\mathrm{pH}$ and alkalinity in the Tweed Estuary, UK. Sci. Total Environ. 251:125-138.

Josefson, A. B. \& B. Rasmussen. 2000. Nutrient retention by benthic macrofaunal biomass of Danish estuaries: importance of nutrient load and residence time. Estuar. Coast. Shelf Sci. 50:205-216.

Karydis, M. \& G. Tsirtsis. 1996. Ecological indices: a biometric approach for assessing eutrophication levels in the marine environment. Sci. Total Environ. 186:209-219.

Kelly, M. G. 1998. Use of community-based indices to monitor eutrophication in European rivers. Environ. Conserv. 25:22-29.

Kroeker, K. J., F. Micheli, M. C. Gambi \& T. R. Martz. 2011. Divergent ecosystem responses within a benthic marine community to ocean acidification. Proc. Natl. Acad. Sci. USA 108:14515-14520.

Lejart, M. \& C. Hily. 2011. Differential response of benthic macrofauna to the formation of novel oyster reefs (Crassostrea gigas, Thunberg) on soft and rocky substrate in the intertidal of the Bay of Brest, France. J. Sea Res. 65:84-93.

Lewis, C., K. Clemow \& W. V. Holt. 2012. Metal contamination increases the sensitivity of larvae but not gametes to ocean acidification in the polychaete Pomatoceros lamarckii (Quatrefages). Mar. Biol. 160:2089-2101.

Macdonald, B. C. T., I. White, M. E. Åström, A. F. Keene, M. D. Melville \& J. K. Reynolds. 2007. Discharge of weathering products from acid sulfate soils after a rainfall event, Tweed River, eastern Australia. Appl. Geochem. 22:2695-2705.

Marshall, D. J., J. H. Santos, K. M. Y. Leung \& W. H. Chak. 2008. Correlations between gastropod shell dissolution and water chemical properties in a tropical estuary. Mar. Environ. Res. 66:422-429.

Mccormick, P. V. \& R. J. Stevenson. 2007. Effects of snail grazing on benthic algal community structure in different nutrient environments. J. North Am. Benthol. Soc. 8:162-172.

Michaelidis, B., C. Ouzounis, A. Paleras \& H. O. Portner. 2005. Effects of long-term moderate hypercapnia on acid-base balance and growth rate in marine mussels Mytilus galloprovincialis. Mar. Ecol. Prog. Ser. 293:109-118. 
Nath, B., G. Birch \& P. Chaudhuri. 2013. Trace metal biogeochemistry in mangrove ecosystems: a comparative assessment of acidified (by acid sulfate soils) and non-acidified sites. Sci. Total Environ. 463464:667-674.

Nixon, S. W. \& B. A. Buckley. 2002. "A strikingly rich zone": nutrient enrichment and secondary production in coastal marine ecosystems. Estuaries 25:782-796.

Nixon, S. W., C. A. Oviatt, J. Frithsen \& B. Sullivan. 1986. Nutrients and the productivity of estuarine and coastal marine ecosystems. $J$. Limnol. Soc. South. Afr. 12:43-71.

Proum, S., C. D. Harley, M. Steele \& D. J. Marshall. 2017. Aerobic and behavioral flexibility allow estuarine gastropods to flourish in rapidly changing and extreme $\mathrm{pH}$ conditions. Mar. Biol. 164:1-14.

Provoost, P., S. Van Heuven, K. Soetaert, R. W. P. M. Laane \& J. J. Middelburg. 2010. Seasonal and long-term changes in $\mathrm{pH}$ in the Dutch coastal zone. Biogeosciences 7:3869-3878.

R Core Team. 2017. R: a language and environment for statistical computing. Vienna, Austria: R Foundation for Statistical Computing.

Rapport, D. J. \& W. G. Whitford. 1999. How ecosystems respond to stress. Bioscience 49:193-203.

Ringwood, A. H. \& C. J. Keppler. 2002. Water quality variation and clam growth: is pH really a non-issue in estuaries? Estuaries 25:901-907.

Rosemond, A. D. \& S. R. Reice. 1992. The effects of stream acidity on benthic invertebrate communities in the southeastern United States. Freshw. Biol. 27:193-209.

Ruiz-Halpern, S., D. T. Maher, I. R. Santos \& B. D. Eyre. 2015. High $\mathrm{CO}_{2}$ evasion during floods in an Australian subtropical estuary downstream from a modified acidic floodplain wetland. Limnol. Oceanogr. 60:42-56.

Sammut, J., M. D. Melville, R. B. Callinan \& G. C. Fraser. 1995. Estuarine acidification: impacts on aquatic biota of draining acid sulphate soils. Aust. Geogr. Stud. 33:89-100.

Scheffer, M., S. Carpenter, J. A. Foley, C. Folke \& B. Walker. 2001. Catastrophic shifts in ecosystems. Nature 413:591-596.

Sousa, W. P. 1979. Disturbance in marine intertidal boulder fields: the nonequilibrium maintenance of species diversity. Ecology 60:1225-1239.
Strahl, J., T. Brey, E. E. R. Philipp, G. Thorarinsdottir, N. Fischer, W. Wessels \& D. Abele. 2011. Physiological responses to self-induced burrowing and metabolic rate depression in the ocean quahog Arctica islandica. J. Exp. Biol. 214:4223-4233.

Summerhayes, S. A., M. J. Bishop, A. Leigh \& B. P. Kelaher. 2009. Effects of oyster death and shell disarticulation on associated communities of epibiota. J. Exp. Mar. Biol. Ecol. 379:60-67.

Tulau, M. J. 1999. Acid sulfate soil management priority areas in the Lower Hastings-Camden Haven floodplains. Report. Sydney, Australia: NSW Department of Land and Water Conservation. $51 \mathrm{pp}$.

Underwood, A. J. 1997. Experiments in ecology: their logical design and interpretation using analysis of variance. Cambridge, UK: Cambridge University Press. $532 \mathrm{pp}$

Waldbusser, G. G., E. P. Voigt, H. Bergschneider, M. A. Green \& R. I. E. Newell. 2011. Biocalcification in the eastern oyster (Crassostrea virginica) in relation to long-term trends in Chesapeake Bay $\mathrm{pH}$. Estuar. Coasts 34:221-231.

Weisberg, S. B., J. A. Ranasinghe, D. M. Dauer, L. C. Schaffner, R. J. Diaz \& J. B. Frithsen. 1997. An estuarine benthic index of biotic integrity (B-IBI) for Chesapeake Bay. Estuaries 20: $149-158$.

Whiteley, N. M. 2011. Physiological and ecological responses of crustaceans to ocean acidification. Mar. Ecol. Prog. Ser. 430: $257-271$.

Whitfield, A. K. 2016. Biomass and productivity of fishes in estuaries: a South African case study. J. Fish Biol. 89:1917-1930.

Widdicombe, S. \& J. I. Spicer. 2008. Predicting the impact of ocean acidification on benthic biodiversity: what can animal physiology tell us? J. Exp. Mar. Biol. Ecol. 366:187-197.

Wilson, B. P., I. White \& M. D. Melville. 1999. Floodplain hydrology, acid discharge and change in water quality associated with a drained acid sulfate soil. Mar. Freshw. Res. 50:149-157.

Wilson, S. P. \& R. V. Hyne. 1997. Toxicity of acid-sulfate soil leachate and aluminum to embryos of the Sydney rock oyster. Ecotoxicol. Environ. Saf. 37:30-36.

\section{APPENDIX}
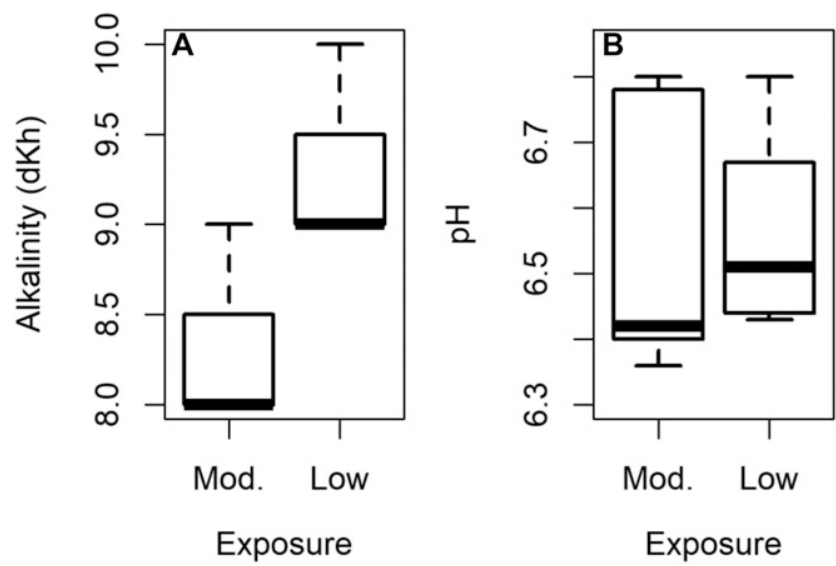

Figure A1. Median (A) alkalinity and (B) pH for low-exposure (Low) and moderate-exposure (Mod.) sites in the Hastings Estuary. Boxes extend from the first to third quartile with a horizontal line at the median. Whiskers extend from the lowest data point that is still within $1.5 \mathrm{IQR}$ of the lower quartile to the highest data point still within $1.5 \mathrm{IQR}$ of the upper quartile. 